\title{
Studi Eksperimental Beton Mutu Normal Dengan Agregat Batok Kelapa Dan Terak Nikel
}

\author{
Putri Aprilia*1, Frans Phengkarsa*2, Benny Kusuma ${ }^{3}$ \\ *1 Mahasiswa Program Studi Teknik Sipil, Universitas Kristen Indonesia Paulus Makassar, \\ Indonesia putriapriliapaindan@gmail.com \\ ${ }^{* 2,3}$ Dosen Program Studi Teknik Sipil, Universitas Kristen Indonesia Paulus Makassar, Indonesia ${ }^{2}$ \\ fphengkarsa@hotmail.com $*^{2}$ dan kusumab06@yahoo.com*3
}

Corresponding Author: kusumab06@yahoo.com

\begin{abstract}
Abstrak
Penelitian ini bertujuan untuk mengetahui nilai kuat tekan, kuat tarik belah, kuat lentur, serta modulus elastisitas pada beton mutu normal dengan variasi bahan tambah batok kelapa dan terak nikel pada agregat kasar. Pembuatan benda uji berupa silinder $150 \mathrm{~mm}$ x $150 \mathrm{~mm}$ x $300 \mathrm{~mm}$ sebanyak 27 buah dan balok $150 \mathrm{~mm} \times 150 \mathrm{~mm} \times 600 \mathrm{~mm}$ sebanyak 9 buah. Hasil penelitian menunjukkan penambahan batok kelapa dan terak nikel pada agregat kasar terhadap pengujian beton dengan komposisi campuran terak nikel 30\% dan batok kelapa 20\% diperoleh nilai berturut-turut untuk kuat tekan hari ke-28 yaitu 30,841 MPa, 31,124 MPa dan 31,690 MPa, kuat tarik belah berturut-turut yaitu 3,114 MPa, 3,468 Mpa dan 3,255 MPa, nilai kuat lentur berturut-turut adalah 4,383 MPa, 4,018 Mpa dan 3,930 MPa. Dan untuk nilai modulus elastisitas diperoleh nilai berturut-turut 12763,274 MPa, 15404,333 MPa, dan 13619,275 MPa.
\end{abstract}

Kata kunci: Batok Kelapa, Terak Nikel, Beton Mutu Normal.

\begin{abstract}
This study aims to determine the value of compressive strength, split tensile strength, flexural strength, and modulus of elasticity in normal quality concrete with variations of coconut shell and nickel slag added materials in coarse aggregate. Making test objects in the form of cylinders $150 \mathrm{~mm}$ $\times 150 \mathrm{~mm} \times 300$ as many as 27 pieces and beams $150 \mathrm{~mm} \times 150 \mathrm{~mm} \times 600 \mathrm{~mm}$ as many as 9 pieces. The results showed that the addition of coconut shells and nickel slag to coarse aggregate for testing concrete with a mixture of $30 \%$ nickel slag and $20 \%$ coconut shells obtained values for the 28 th day of compressive strength, namely 30,841MPa, 31,124MPa and 31,690MPa, strong Split tensile strength is 3,114MPa, 3,468MPa and 3,255MPa, respectively, the flexural strength values are 4,383MPa, 4,018MPa and 3,930MPa, respectively. And for the modulus of elasticity, the values obtained are 12763,274MPa, 15404,333MPa, and 13619,275MPa.
\end{abstract}

Keywords: coconut shell, Nickel Slag, Normal Quality Concrete.

\section{PENDAHULUAN}

Beton merupakan salah satu bahan konstruksi struktur jalan, jembatan dan bangunan lainnya. Penggunaan beton sering digunakan dalam konstruksi bangunan karena memiliki kelebihan dalam mendukung tegangan tekan, mudah dalam pelaksanaan, perawatan yang murah. Seperti kita ketahui bersama, bahan yang 
digunakan untuk membuat beton terdiri dari agregat kasar (batu pecah, kerikil dan jenis agregat lainnya), agregat halus(pasir), semen dan bahan tambahan lainnya.

Secara volumentris beton diisi oleh agregat sebanyak 61-76\% (Paul. N Antoni, 2007) jadi agregat mempuyai peranan penting sebagai material pengisi beton. Hal tersebut mengakibatkan persediaan agregat dibeberapa tempat menjadi langka serta harga jualnya yang meningkat akibat permintaan industri konstruksi yang besar. Salah satu alternatif material yang bisa digunakan untuk pengganti material agregat kasar adalah dengan memanfaatkan limbah industri seperti batok kelapa dan terak nikel.

Beton mutu normal adalah beton yang memiliki berat jenis antara $2200-2500 \mathrm{~kg} / \mathrm{m}^{3}$ dengan kuat tekan sekitar 15-40 MPa. Material Penyusun Beton adalah Semen Portland, Agregat Kasar (Batu Pecah), Agregat Halus (Pasir), Air.

Penelitian ini bertujuan untuk menentukan karakteristik beton dengan batok kelapa sebagai bahan agrgat kasar melalui uji kuat tekan, kuat tarik belah, kuat lentur dan modulus elastisitas. Dalam penelitian ini batok kelapa dipecahkan menjadi ukuran yang lebih kecil dengan ukuran 10-15 mm atau yang lolos saringan 25 mm x 25 mm, dengan komposisi bahan pengisi agregat kasar sebanyak 20\%.

Limbah nikel merupakan sejenis batuan hasil pembuangan dari sisa pengolahan nikel yang memiliki sifat sifat menyerupai batu dan memiliki kandungan unsur silikat serta kapur yang cukup tinggi yang diharapkan dapat memperkuat perbandingan agregat dengan pasta, sehingga meminimalisir kehancuran beton,dengan demikian kekuatan beton yang diinginkan dapat tercapai.

Kuat Tekan Beton adalah besarnya beban per satuan luas yang menyebabkan benda uji beton hancur bila dibebani dengan gaya tekan tertentu, yang dihasilkan oleh mesin tekan.

$$
f_{c}^{\prime}=\frac{P}{A}
$$

Kuat Tarik Belah Beton adalah tarik belah yang diperoleh berdasarkan beban yang mampu diterima beton pada sisi panjangnya sampai terjadi belah.

$$
\mathrm{T} \quad=\frac{2 \mathrm{P}}{\pi \mathrm{Ld}}
$$

Kuat Lentur Beton ialah kemampuan beton yang diletakkan pada dua perletakan untuk menahan gaya dengan arah tegak lurus sumbu benda uji yang diberikan kepadanya sampai benda uji patah (SNI 4431:2011).

$$
\begin{aligned}
& \sigma=\frac{P . L}{b \cdot h^{2}} \\
& \sigma=\frac{P . a}{b \cdot h^{2}}
\end{aligned}
$$

Modulus Elastisitas Modulus elastisitas ditentukan dari perubahan tegangan terhadap regangan dalam batas elastisnya.

$$
\mathrm{Ec}=\frac{\mathrm{S} 2-\mathrm{S} 1}{\varepsilon 2-0,00005}
$$




\section{METODOLOGI}

Lokasi pengambilan batok kelapa berada di pasar Daya, Kota Makassar, Provinsi Sulawesi Selatan dan Lokasi pengambilan terak nikel berada di PT. Vale Indonesia, Jl. D. Towuti No. 44, Sorowako, Kecamatan Nuha, Kabupaten Luwu Timur, Sulawesi Selatan.

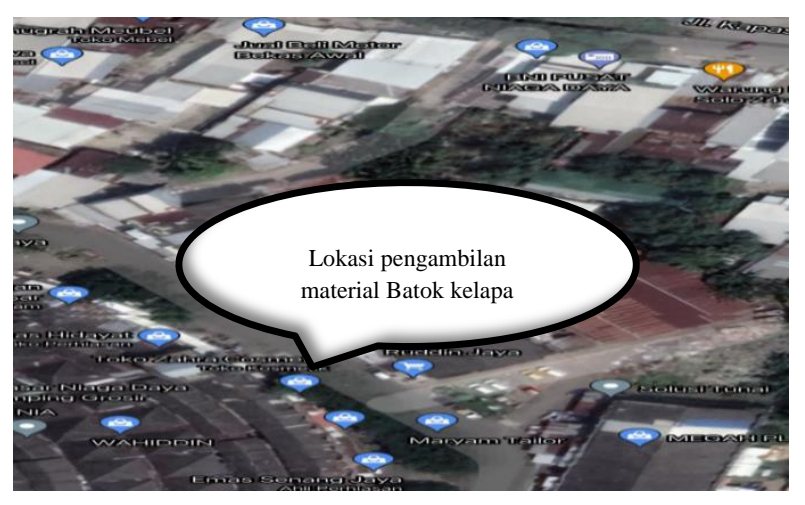

Gambar 1 Lokasi pengambilan batok kelapa

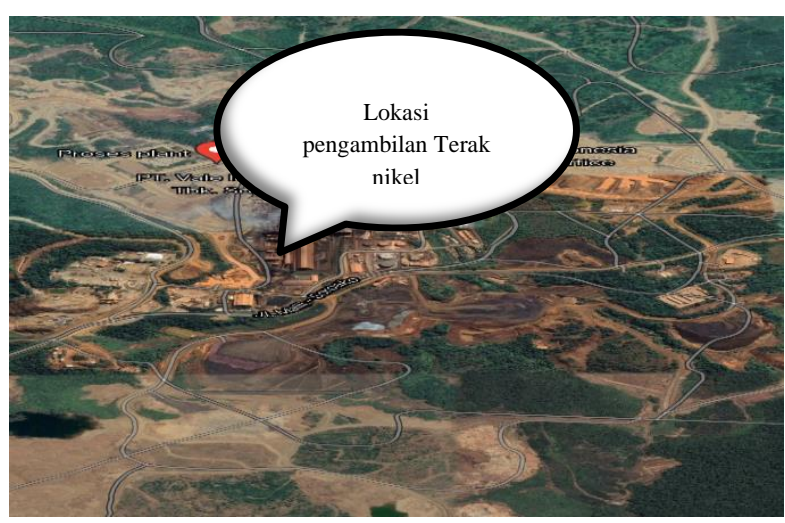

Gambar 2 Lokasi pengambilan terak nikel

\section{ANALISA DAN PEMBAHASAN}

1. Pemeriksaan Karakteristik Material

Material yang dipakai dalam campuran beton harus diuji karakteristiknya sebelum digunakan untuk menjamin kualitasnya.

Tabel 1.Spesifikasi Karakteristik Agregat Halus

\begin{tabular}{ccc}
\hline Karakteristik Agregat Halus & Interval Batas & Pedoman \\
\hline Kadar lumpur, $\%$ & $0,2-6$ & SNI 03 $-4142: 1996$ \\
\hline Kadar organik, warna & $<$ No.3 & $2816: 2014$ \\
\hline Kadar air, $\%$ & $3-5$ & SNI $03-1971: 2011$ \\
\hline Berat volume padat, kg/liter & $1,4-1,9$ & SNI 03 $-4804: 1998$ \\
\hline Berat volume gembur, kg/liter & $0,2-2$ & SNI 03 $-4804: 1998$ \\
\hline Penyerapan, $\%$ & $0,2-2$ & SNI $1970: 2008$ \\
\hline Berat jenis(SSD) & $1,6-3,2$ & SNI $1970: 2008$ \\
\hline
\end{tabular}




\begin{tabular}{|c|c|c|}
\hline Modulus kehalusan & $2,2-3,1$ & SNI 03- $1968: 1990$ \\
\hline \multicolumn{3}{|c|}{ Tabel 2. Spesifikasi karakteristik agregat $\mathrm{k}$ asar } \\
\hline Karakteristik Agregat Kasar & Interval Batas & Pedoman \\
\hline Kadar Lumpur,\% & $0,2-1$ & SNI $03-4142-1996$ \\
\hline Kadar Air, $\%$ & $0,5-2$ & SNI $03-1971-2011$ \\
\hline Berat volume padat, $\mathrm{kg} / \mathrm{liter}$ & $1,4-1,9$ & SNI $03-4804-1998$ \\
\hline Berat volume gembur, $\mathrm{kg} / \mathrm{liter}$ & $1,4-1,9$ & SNI $03-4804-1998$ \\
\hline Penyerapan, $\%$ & $0,2-2$ & SNI 1969- 2008 \\
\hline Berat jenis(SSD) & $1,6-3,2$ & SNI $1969-2008$ \\
\hline
\end{tabular}

\section{Identifikasi Benda Uji}

Silinder berukuran $15 \mathrm{~cm} \times 30 \mathrm{~cm}$ untuk pengujian kuat tekan beton, kuat tarik belah beton, dan modulus elastisitas. Balok berukuran $60 \mathrm{~cm} \times 15 \mathrm{~cm} \times 15 \mathrm{~cm}$ untuk pengujian kuat lentur beton.

Tabel 3 Identifikasi Benda Uji

\begin{tabular}{|c|c|c|c|c|}
\hline $\begin{array}{l}\text { Agregat yang } \\
\text { digunakan }\end{array}$ & pengujian & Umur sampel & Bentuk sampel & Jumlah sampel \\
\hline \multirow{4}{*}{$\begin{array}{c}\text { Batu pecah } \\
100 \%\end{array}$} & $\begin{array}{c}\text { Kuat Tekan } \\
\text { Beton }\end{array}$ & $\begin{array}{c}7 \text { hari, } 21 \text { hari, } \\
28 \text { hari }\end{array}$ & Silinder $15 \mathrm{~cm} \times 30 \mathrm{~cm}$ & 9 \\
\hline & $\begin{array}{l}\text { Kuat Tarik } \\
\text { Belah Beton }\end{array}$ & 28 hari & Silinder $15 \mathrm{~cm} \times 30 \mathrm{~cm}$ & 3 \\
\hline & $\begin{array}{l}\text { Kuat Lentur } \\
\text { Beton }\end{array}$ & 28 hari & $\begin{array}{c}\text { Balok } \\
60 \mathrm{~cm} \times 15 \mathrm{~cm} \times 15 \mathrm{~cm}\end{array}$ & 3 \\
\hline & $\begin{array}{l}\text { Modulus } \\
\text { Elastisitas } \\
\text { Beton }\end{array}$ & 28 hari & Silinder $15 \mathrm{~cm} \times 30 \mathrm{~cm}$ & 3 \\
\hline \multirow{4}{*}{$\begin{array}{c}\text { Batok kelapa } \\
20 \%, \text { Terak } \\
\text { Nikel } 30 \% \text {, } \\
\text { Batu Pecah } \\
50 \%\end{array}$} & $\begin{array}{c}\text { Kuat Tekan } \\
\text { Beton }\end{array}$ & $\begin{array}{c}7 \text { hari, } 21 \text { hari, } \\
28 \text { hari }\end{array}$ & Silinder $15 \mathrm{~cm} \times 30 \mathrm{~cm}$ & 9 \\
\hline & $\begin{array}{l}\text { Kuat Tarik } \\
\text { Belah Beton }\end{array}$ & 28 hari & Silinder $15 \mathrm{~cm} \times 30 \mathrm{~cm}$ & 3 \\
\hline & $\begin{array}{l}\text { Kuat Lentur } \\
\text { Beton }\end{array}$ & 28 hari & $\begin{array}{c}\text { Balok } \\
60 \mathrm{~cm} \times 15 \mathrm{~cm} \times 15 \mathrm{~cm}\end{array}$ & 3 \\
\hline & $\begin{array}{l}\text { Modulus } \\
\text { Elastisitas } \\
\text { Beton }\end{array}$ & 28 hari & Silinder $15 \mathrm{~cm} \times 30 \mathrm{~cm}$ & 3 \\
\hline
\end{tabular}




\section{Hasil Pemeriksaan Karakteristik Material}

Tabel 4 Hasil Pemeriksaan Karakteristik Agregat Halus

\begin{tabular}{ccccl}
\hline No. & Karakteristik & Hasil & Interval SNI & Ket. \\
\hline 1. & Kadar Air & $3,307 \%$ & $3 \%-5 \%$ & Memenuhi \\
\hline 2. & Kadar Lumpur & $3, .0 \%$ & $0,2 \%-6 \%$ & Memenuhi \\
\hline 3. & Berat Jenis SSD & 2,591 & $1,6-3,2$ & Memenuhi \\
\hline 4. & Penyerapan & $1,730 \%$ & $0,2 \%-2 \%$ & Memenuhi \\
\hline 5. & Berat Volume Padat & $1626,25 \mathrm{~kg} / \mathrm{m}^{3}$ & $1400-1900 \mathrm{~kg} / \mathrm{m}^{3}$ & Memenuhi \\
\hline 6. & Berat Volume & $\begin{array}{c}1585,485 \\
\mathrm{~kg} / \mathrm{m}^{3}\end{array}$ & $1400-1900 \mathrm{~kg} / \mathrm{m}^{3}$ & Memenuhi \\
\hline 7. & Modulus Kehalusan & 2,600 & $2,2-3,1$ & Memenuhi \\
\hline
\end{tabular}

Tabel 5 Hasil Pemeriksaan Karakteristik Agregat Kasar

\begin{tabular}{ccccl}
\hline No. & Karakteristik & Hasil & Interval SNI & Ket. \\
\hline 1. & Kadar lumpur, $\%$ & 0,4 & $0,2-1$ & Memenuhi \\
\hline 2. & Kadar air, $\%$ & 0,6 & $0,5-2,0$ & Memenuhi \\
\hline 3. & $\begin{array}{c}\text { Berat volume } \\
\text { padat,kg/liter }\end{array}$ & 1,485 & $1,40-1,90$ & Memenuhi \\
\hline 4. & $\begin{array}{c}\text { Berat volume } \\
\text { gembur,kg/liter }\end{array}$ & 1,452 & $1,40-1,90$ & Memenuhi \\
\hline 5. & Penyerapan, $\%$ & 1,585 & $0,20-2,00$ & Memenuhi \\
\hline 6. & Berat jenis(SSD) & 2,596 & $1,6-3,2$ & Memenuhi \\
\hline
\end{tabular}

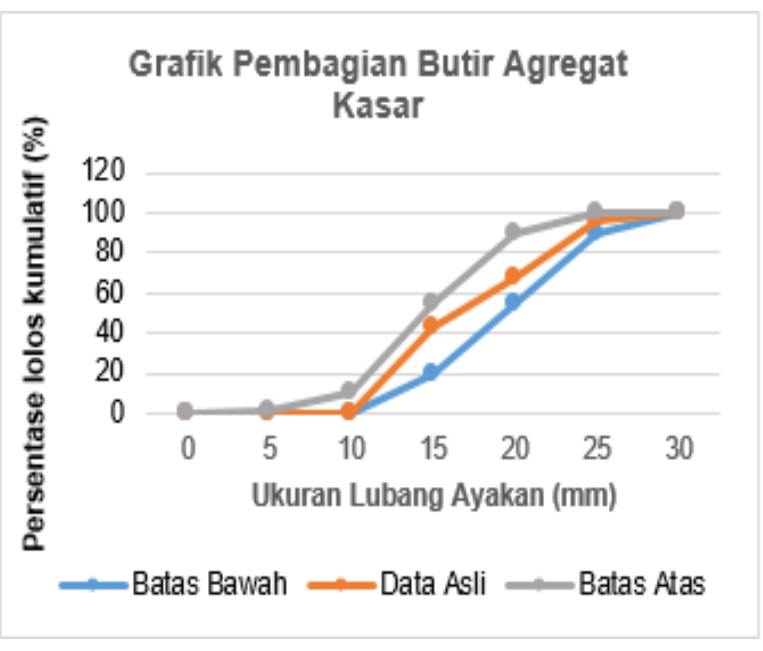

Gambar 3.Grafik pembagian butir agregat kasar

\section{Design Metode ACI}

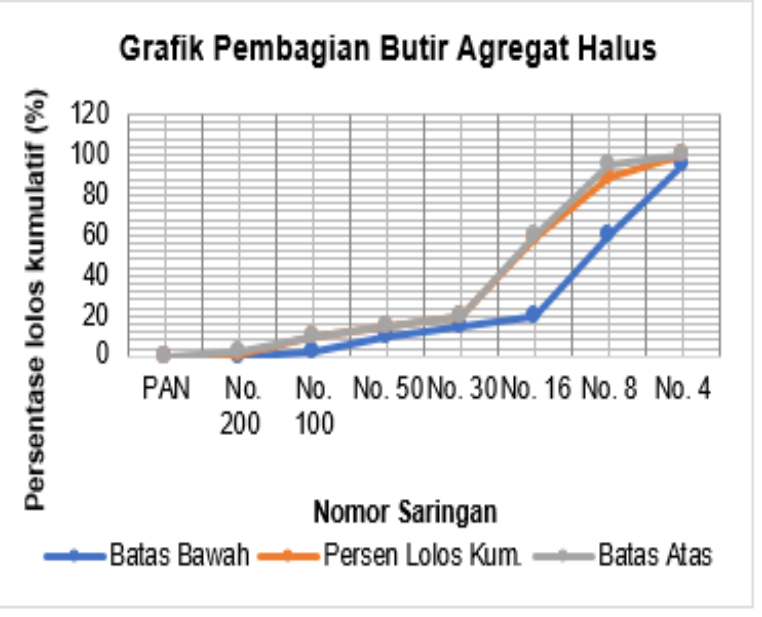

Gambar 4.Grafik pembagian butir agregat halusMix 
Mix design yang dilakukan pada penelitian ini adalah Metode American Concrete Institute (ACI). Dalam Mix Design ini peneliti merancang mutu rencana (f'c) sebesar $30 \mathrm{MPa}$.

\section{Hasil Pemeriksaan Kuat Tekan Beton}

Pengujian kuat tekan beton dilakukan agar diketahui kekuatan betom menerima beban tekan $(\mathrm{kN})$.

Tabel 6. Komposisi Campuran Beton

\begin{tabular}{ccc}
\hline No. & Material & Berat $(\mathrm{Kg})$ \\
\hline 1. & Agregat Halus & $660,705 \mathrm{Kg} / \mathrm{m}^{3}$ \\
\hline 2. & Semen & $448,837 \mathrm{Kg} / \mathrm{m}^{3}$ \\
\hline 3. & Air & $193 \mathrm{Kg} / \mathrm{m}^{3}$ \\
\hline 4. & Batu Pecah & $512,325 \mathrm{Kg} / \mathrm{m}^{3}$ \\
\hline 5. & Terak Nikel & $307,395 \mathrm{Kg} / \mathrm{m}^{3}$ \\
\hline 6. & Batok Kelapa & $204,930 \mathrm{Kg} / \mathrm{m}^{3}$ \\
\hline
\end{tabular}

Tabel 7 Hasil Pengujian Kuat Tekan Beton

\begin{tabular}{|c|c|c|c|c|c|}
\hline Variasi & $\begin{array}{l}\text { Umur } \\
\text { (Hari) }\end{array}$ & $\begin{array}{c}\text { Beban } \\
\text { Maksimum }(\mathrm{kN})\end{array}$ & $\begin{array}{c}\text { Kuat Tekan } \\
\text { Aktual (MPa) }\end{array}$ & $\begin{array}{c}\text { Rata-Rata Kuat } \\
\text { Tekan Aktual } \\
\text { (MPa) }\end{array}$ & $\begin{array}{c}\text { Rata-Rata } \\
\text { Kuat Tekan } \\
28 \text { hari }(\mathrm{MPa})\end{array}$ \\
\hline \multirow{9}{*}{$\begin{array}{c}50 \% \text { Batu } \\
\text { Pecah, 30\% } \\
\text { Terak Nikel, } \\
20 \% \text { Batok } \\
\text { Kelapa } \\
28 \text { hari }\end{array}$} & \multirow{3}{*}{7} & 355 & 20.089 & \multirow{3}{*}{19,523} & \multirow{3}{*}{30,035} \\
\hline & & 335 & 18.957 & & \\
\hline & & 345 & 19.523 & & \\
\hline & \multirow{3}{*}{21} & 520 & 29.426 & \multirow{3}{*}{29,237} & \multirow{3}{*}{30,776} \\
\hline & & 505 & 28.577 & & \\
\hline & & 525 & 29.709 & & \\
\hline & \multirow{3}{*}{28} & 545 & 30.841 & \multirow{3}{*}{31.218} & \multirow{3}{*}{31.218} \\
\hline & & 550 & 31.124 & & \\
\hline & & 560 & 31.690 & & \\
\hline
\end{tabular}

\section{KUAT TEKAN VS UMUR BETON}
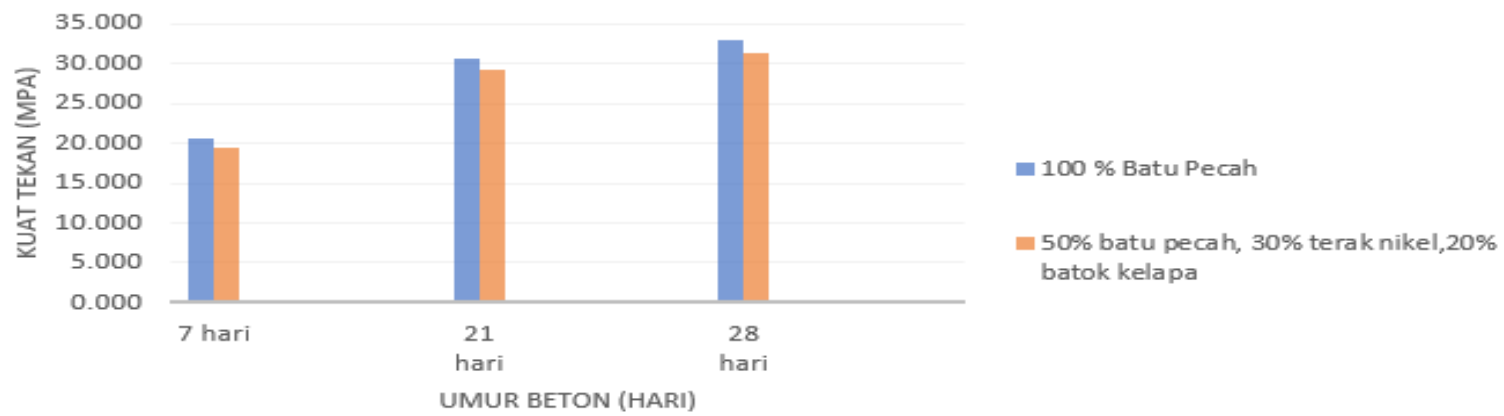

Gambar 5 kuat tekan terhadap umur beton 
Dari grafik hubungan antara kuat tekan dengan umur beton menunjukkan bahwa semakin bertambahnya umur beton maka nilai kuat beton semakin meningkat. Nilai kuat tekan beton yang menggunakan $100 \%$ kerikil lebih tinggi dari pada beton yang menggunakan substitusi batok kelapa dan terak nikel dengan nilai kuat rencana 30 Mpa pada umur 28 Hari sebesar 33,010 dan 31,218.

\section{Hasil Pengujian Kuat Tarik Belah Beton}

Setelah mencapai umur rencana perawatan benda uji 28 hari, maka setiap benda uji dibagi berdasarkan variasi substitusi yang digunakan, kemudian dilakukan pengujian kuat tarik belah di laboratorium. Berikut hasil perhitungan dari kuat tarik belah dari substitusi terak nikel 30\% dan batok kelapa $20 \%$.

Tabel 8 Hasil Pengujian Kuat Tarik belah Beton

\begin{tabular}{cccc}
\hline Agregat Kasar & Beban Maksimum $(\mathrm{kN})$ & $\begin{array}{c}\text { Kuat Tarik Belah } \\
\text { Aktual (MPa) }\end{array}$ & $\begin{array}{c}\text { Rata-rata kuat tarik } \\
\text { belah actual }\end{array}$ \\
\cline { 1 - 3 } $\begin{array}{c}\text { Batok Kelapa 20\%, } \\
\text { Terak Nikel 30\%, } \\
\text { dan Batu Pecah } \\
\text { 50\% }\end{array}$ & 220 & 3,11394 & 3,27908 \\
\hline
\end{tabular}

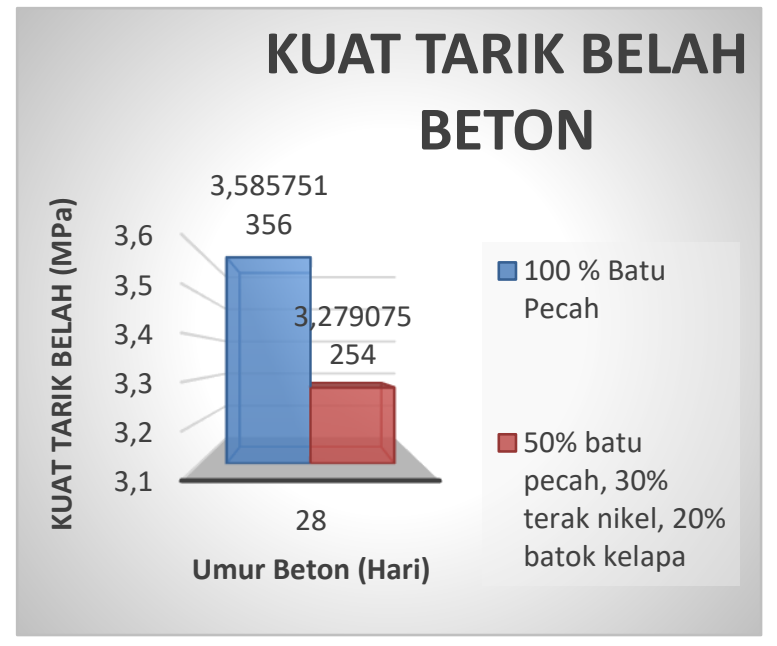

Gambar 6 Grafik kuat tarik belah beton

Dari grafik kuat tarik belah beton menunjukkan bahwa nilai kuat tarik beton semakin meningkat. Nilai kuat tarik belah beton yang menggunakan $100 \%$ kerikil lebih tinggi dari pada beton yang menggunakan subtitusi batok kelapa dan terak nikel dengan nilai kuat rencana 30 Mpa pada umur 28 Hari sebesar 3,586 dan 3,279.

\section{Hasil Pengujian Kuat Lentur Beton}

Pengujian kuat lentur balok dilakukan pada umur 28 hari dengan menggunakan balok berukuran $60 \times 15 \times 15$ $\mathrm{cm}$. Pengujian ini dimaksudkan untuk mengetahui kemampuan balok beton untuk menahan gaya yang diletakkan pada dua perletakan hingga patah.

Tabel 9 Hasil Pengujian Kuat Lentur Beton

\begin{tabular}{cccc}
\hline Agregat kasar & Beban Maksimum(Ton) & $\begin{array}{c}\text { Kuat Lentur Beton } \\
(\mathrm{MPa})\end{array}$ & $\begin{array}{c}\text { Kuat Lentur Beton } \\
\text { Aktual Rata-rata(MPa) }\end{array}$ \\
\hline Batok Kelapa 20\%, & 2,9 & 4,383 & 4,131 \\
\hline
\end{tabular}




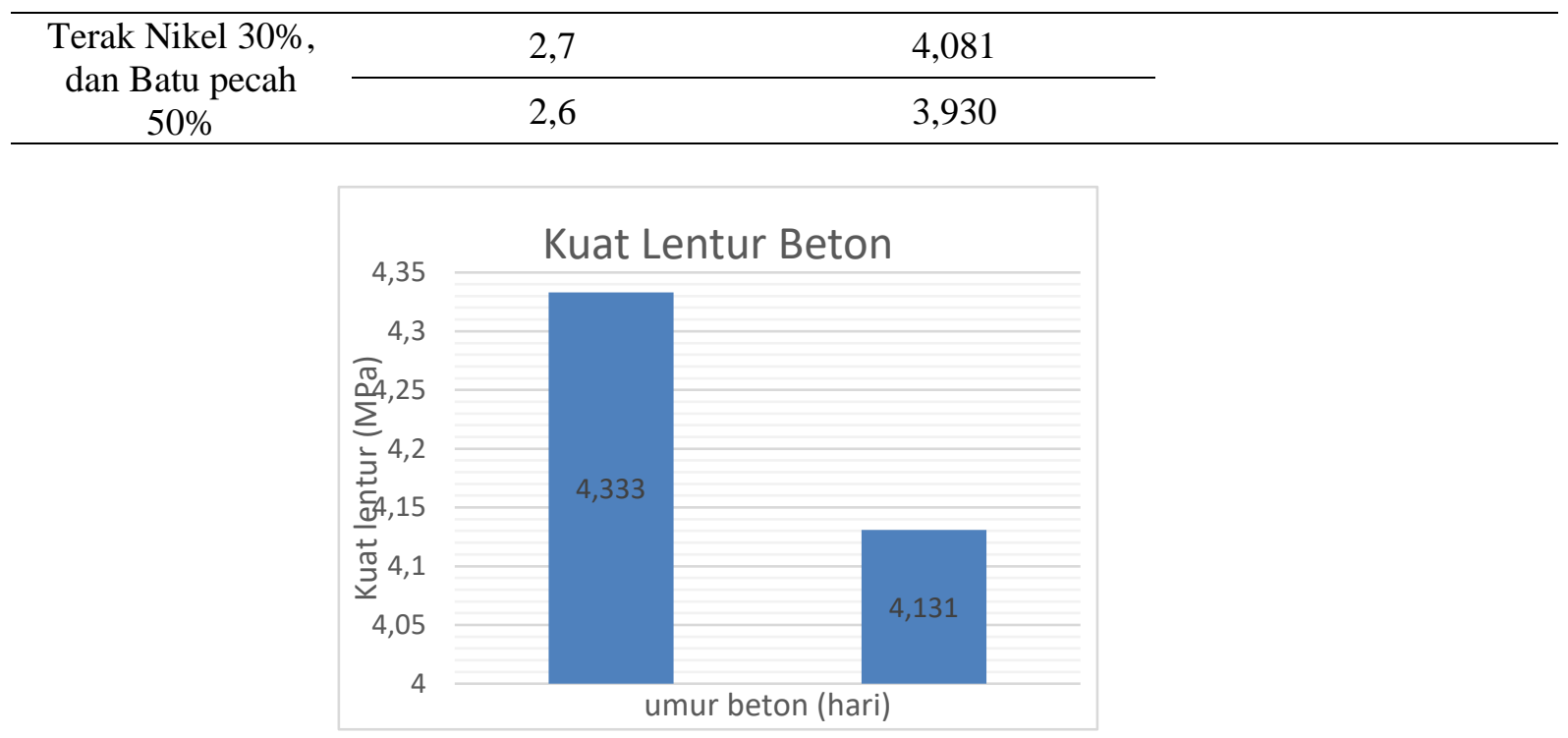

Gambar 7 Grafik Pengujian Kuat Lentur Beton

Dari grafik antara kuat lentur beton menunjukkan bahwa nilai kuat tekan beton yang menggunakan 100\% kerikil lebih tinggi dari pada beton yang menggunakan substitusi batok kelapa dan terak nikel dengan nilai kuat rencana 30 Mpa pada umur 28 Hari sebesar 4,333 dan 4,131.

\section{Pengujian Modulus Elastisitas Beton}

Pengujian modulus elastisitas beton bertujuan untuk mengetahui besarnya beban yang dapat dipikul tanpa merusak beton itu sendiri. Pengujian modulus elastisitas beton dilakukan pada umur beton 28 hari.

Tabel 10 Hasil Pengujian Modulus Elastisitas Beton

\begin{tabular}{|c|c|c|c|c|c|c|c|}
\hline $\begin{array}{l}\text { Agregat } \\
\text { Kasar }\end{array}$ & Umur & $\begin{array}{l}\text { Bentuk } \\
\text { Benda Uji } \\
(\mathrm{cm})\end{array}$ & Regangan & Tegangan & $\begin{array}{c}\text { Modulus } \\
\text { Elastisitas } \\
(\mathrm{MPa})\end{array}$ & $\begin{array}{l}\text { Rata-rata } \\
\text { Modulus } \\
\text { Elastisitas }\end{array}$ & $\begin{array}{c}\text { Modulus } \\
\text { Elastisitas } \\
\text { Teoritis }\end{array}$ \\
\hline $\begin{array}{c}\text { Batok } \\
\text { Kelapa } 20 \%,\end{array}$ & \multirow{3}{*}{28 hari } & \multirow{3}{*}{$\begin{array}{l}\text { Silider } \\
30 \times 15\end{array}$} & 0,000686 & 17,805 & $19,105,970$ & \multirow{3}{*}{$18,497,191$} & \multirow{3}{*}{$26,141,046$} \\
\hline $\begin{array}{c}\text { Terak Nikel } \\
30 \%\end{array}$ & & & 0,000651 & 16,062 & $17,759,472$ & & \\
\hline $\begin{array}{c}\text { Batu Pecah } \\
50 \%\end{array}$ & & & 0,000600 & 16,737 & $18,626,130$ & & \\
\hline
\end{tabular}




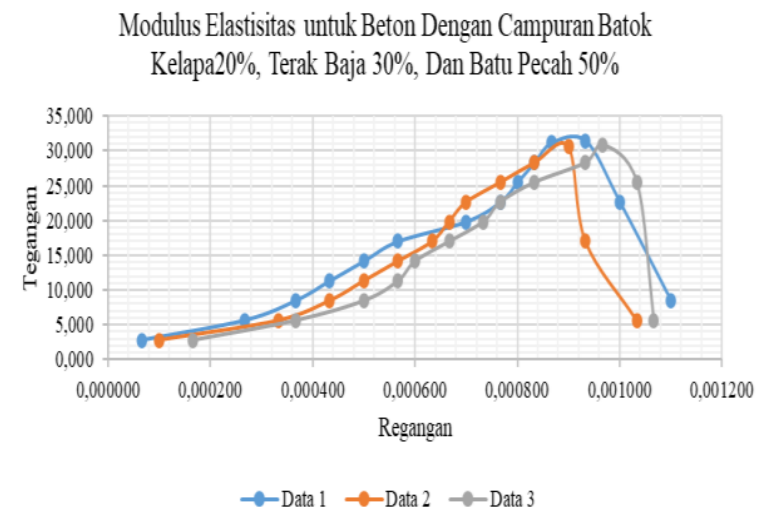

Gambar 8 grafik modulus elastisitas beton

Hasil pengujian menunjukkan nilai Modulus elastisitas pada beton yang menggunakan campuran agregat kasar (Batu pecah 100\%) lebih tinggi dengan nilai pada data 1 sebesar 21211,314 MPa, data 2 sebesar 18898,606 MPa, data 3 sebesar $20902 \mathrm{MPa}$, dibandingkan dengan beton yang menggunakan campuran agregat kasar (Batok kelapa 20\%, Terak Nikel 30\%, dan batu pecah 50\%) dengan nilai modulus elastisitas pada data 1 sebesar 19105,970 MPa, data 2 sebesar 17759,472 MPa, dan data 3 sebesar 18626,130 MPa.

\section{Hubungan Antara Kuat Tekan dengan Kuat tarik belah}

pada variasi $100 \%$ kerikil, nilai kuat tarik belah sebesar 10,863\% dari nilai kuat tekan, pada variasi (50\% Kerikil, Terak Nikel 30\%, Batok Kelapa 20\%) diperoleh nilai kuat tarik belah sebesar 10,504\% dari nilai kuat tekannya.

\section{Hubungan Antara Kuat Tekan dengan Kuat Lentur}

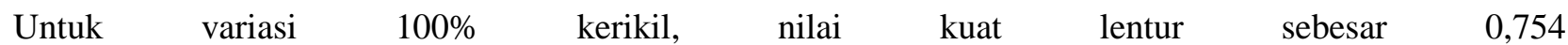
$\sqrt{f^{\prime} c}$ dari nilai kuat tekan, pada variasi (50\% Kerikil, Terak Nikel 30\%, Batok Kelapa 20\%) diperoleh nilai kuat lentur sebesar $0,739 \sqrt{f^{\prime} c}$ dari nilai kuat tekan.

\section{Hubungan Antara Kuat Tekan dengan Modulus Elastisitas}

Hubungan antara kuat tekan beton dengan modulus elastisitas dimana semakin besar nilai kuat tekan beton maka semakin besar pula nilai modulus elastisitasnya.

\section{KESIMPULAN}

1. Pengaruh kekuatan beton yang menggunakan substitusi terak nikel sebanyak $30 \%$ dan batok kelapa sebanyak 20\% terhadap agregat kasar masih memenuhi kuat tekan rencana, akan tetapi jika dibandingkan dengan beton yang menggunakan $100 \%$ kerikil untuk agregat kasar menunjukkan bahwa nilai kuat tekan, kuat tarik belah, kuat lentur dan modulus elastisitas untuk beton yang menggunakan $100 \%$ kerikil memiliki nilai lebih besar dari pada beton yang menggunakan subtitusi terak nikel dan batok kelapa.

2. Perbandingan kuat tekan beton yang menggunakan batu pecah $100 \%$ mengalami kenaikan sebesar $10,033 \%$ dari kuat tekan rencana dan beton yang menggunakan batok kelapa $20 \%$, terak baja $30 \%$, dan batu pecah $50 \%$ mengalami kenaikan sebesar $4,060 \%$ dari kuat tekan rencana. Diperoleh nilai kuat tarik belah untuk beton yang menggunakan batu pecah $100 \%$ sebesar $10,863 \%$ dari kuat tekan dan beton yang menggunakan batok kelapa $20 \%$, terak baja $30 \%$, dan batu pecah $50 \%$ nilai kuat tarik belah 
sebesar 10,503\% dari kuat tekan. Nilai kuat lentur untuk beton yang menggunakan batu pecah 100\% sebesar $0,75 \sqrt{f^{\prime} c}$ dari kuat tekan dan pada beton yang menggunakan batok kelapa $20 \%$, terak baja $30 \%$, dan batu pecah $50 \%$ nilai kuat lentur sebesar $0,73 \sqrt{f^{\prime} c}$ dari kuat tekan. Modulus elastisitas yang diperoleh pada beton yang menggunakan batu pecah $100 \%$ sebesar 24257,965 MPa dan untuk beton yang menggunakan batok kelapa $20 \%$, terak baja $30 \%$, dan batu pecah $50 \%$ nilai modulus elastisitas sebesar 18495,544 MPa.

\section{DAFTAR PUSTAKA}

[1] Asroni, Ali. (2010). Balok dan Pelat Beton Bertulang, Penerbit Graha Ilmu, Yogyakarta.

[2] ASTM C 469. "Standard Test Method For Static Modulus Of Elastisitas And Passion' Ratio Of Concrete In Compression".

[3] SNI 03-2491-2014, (2014). Metode Uji Kekuatan Tarik Belah Spesimen Beton Silinder. Jakarta : Badan Standarisasi Nasional.

[4] SNI 1974 : 2011, (2011). Cara Uji Tekan Beton Dengan Benda Uji Silinder, Pusat Penelitian Jalan dan Jembatan. Bandung : Badan Standarisasi Nasional.

[5] SNI 15-2049-2004. (2004). Semen Portland. Badan Standarisasi Nasional. Bandung.

[6] SNI 4431 : 2011. (2011). Cara Uji Kuat Lentur Beton Normal dengan Dua Titik Pembebanan. Jakarta : Badan Standarisasi Nasional.

[7] SNI T-15-1991-03. (1991). Tata Cara Perhitungan Struktur Beton Untuk Bangunan Gedung. Departemen Pekerjaan Umum, Yayasan LPMB, Bandung.

[8] Tjokrodimuljo, K., (2004). Teknologi Beton, Jurusan Teknik Sipil, Fakultas Teknik, Universitas Gadjah Mada, Yogyakarta 